\title{
BUSSINESS PROCESS MANAGEMENT INITIATIVE
}

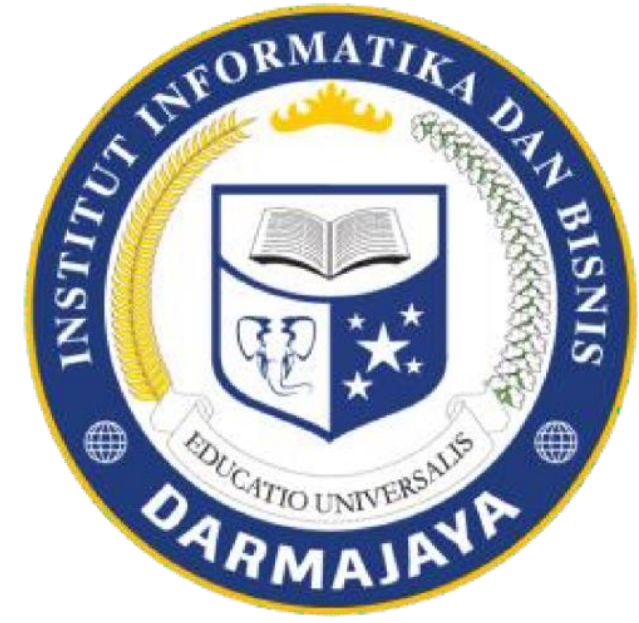

KADEK WAHYU JUNIARTA

1711050053

\section{Institute Informatika \& Bisnis Darmajaya}

\author{
T.A. 2018/2019
}




\section{Kata Pengantar}

Syukur alhamdulillah, merupakan satu kata yang sangat pantas penulis ucakan kepada Allah STW, yang karena bimbingannyalah maka penulis bisa menyelesaikan makalah berjudul BPMN

Saya mengucapkan terimakasih kepada pihak terkait yang telah membantu saya dalam menghadapi berbagai tantangan dalam penyusunan makalah ini. Saya menyadari bahwa masih sangat banyak kekurangan yang mendasar pada makalah ini. Oleh karna itu saya mengundang pembaca untuk memberikan kritik dan saran yang bersifat membangun untuk kemajuan ilmu pengetahuan ini.

Terima kasih, dan semoga makalah ini bisa memberikan sumbangsih positif bagi kita semua. 


\section{A. Pengertian BPMN}

Bussiness Process Modelling Notation adalah suatu standar yang dikembangkan oleh Bussiness Process Management Initiative (BPMI). Tujuan utama dari BPMN adalah menyediakan suatu notasi yang telah dan mudah dipahami oleh semua pebisnis, dari analis bisnis yang menciptakan draft permulaan dari proses-proses sampai dengan pengembanganpengembangan teknis yang bertanggung jawab untuk mengimplementasikan teknologi yang membantu pelaksanaan proses, serta pebisnis kebanyakan yang akan mengatur dan mengawasi proses-proses tersebut.

\section{B. Elemen Dasar}

Ada 4 elemen dasar yang terdapat dalam BPMN yaitu :

1. NOTASI DASAR

2. FLOW OBJECT

3. CONNECTING OBJECT

4. SWIMLANE

\section{Notasi Dasar}

Terdapat juga notasi-notasi dasar yang digunakan dalam BPMN :

1. Circle

2. Activity

3. Gateway

\section{Flowchart Object}

1. Events : events ini mempengaruhi alur proses dan biasanya menyebabkan terjadinya kejadian(trigger) atau sebuah dampak(result). Ada 3 bentuk dari events yaitu start, intermediate dan end

2. Activity : Lambang activity berupa segiempat tumpul dan merupakan bentuk generik dari pekerjaan yang dilakanakan oleh perusahaan. Jenis-jenis activity adalah Task dan SubProses.

3. Gateway: Gateway dilambangkan dengan diamond dan digunakan untuk mengontrol persamaan dan perbedaan dari alur sekuens. Gateway dibagi menjadi dua, menghubungkan dan menggabungkan jalur. 


\section{E. Connecting Object}

Sebuah konektor yang menghubungkan flowchart element/object. Connecting object terbagi menjadi 3.

1. Sequence Flow

Dilambangkan dengan garis yang solid dengan kepala panah yang solid juga dan digunakan untuk menunjukan urutan aktivitas yang akan dilakukan dalam suatu proses.

2. Massage Flow

Dilambangkan dengan garis putus-putus dengan kepala panah terbuka dan digunakan untuk menunjukan alur dari pesan antara dua partisipan proses yang terpisah yang mengirim dan menerima pesan tersebut

\section{Assosiation}

Dilambangkan dengan garis titik-titik dengan kepala panah berbentuk garis dan digunakan untuk menghubungkan data, text dan artifak lain dengan flow object.

\section{F. Swimlane}

Swimlane adalah sebuah mekanisme untuk mengatur aktifitas-aktifitas menjadi kategori visual yang berbeda untuk menunjukan fungsi atau tanggung jawab yang berbeda. Struktur swimlane terbagi menjadi 2 yaitu :

\section{Pool}

Pool meruapakan perwakilan partisipan dalam proses dan juga bertindak sebagai container untuk memisahkan aktifitas dengan pool yang berbeda.

2. Lane

Lane adalah sebuah sub partisi dalam pool dan mengembangkan keseluruhan pool baik secara vertikal maupun horizontal.

\section{G. Artifacts}

Artifacts digunakan untuk memberikan informasi tambahan tentang proses. 


\section{H. Contoh Penggunaan BPMN}

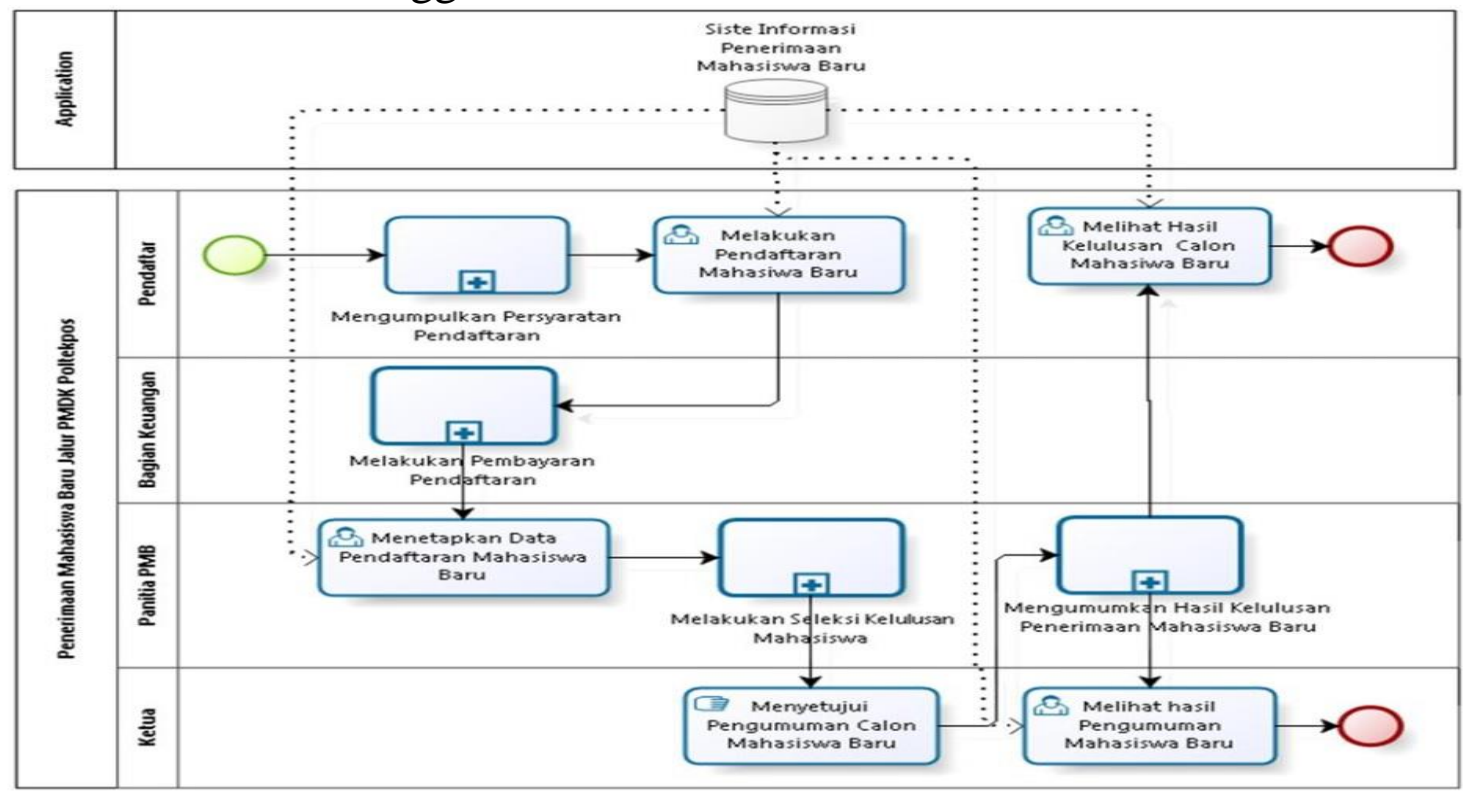




\section{Penutup}

Demikian yang dapat kami paparkan mengenai materi yang menjadi pokok bahasan dalam makalah ini, tentunya masih banyak kekurangan dan kelemahannya, kerena terbatasnya pengetahuan dan kurangnya rujukan atau referensi yang ada hubungannya dengan judul makalah ini.

Penulis banyak berharap para pembaca yang budiman dusi memberikan kritik dan saran yang membangun kepada penulis demi sempurnanya makalah ini dan dan penulisan makalah di kesempatan-kesempatan berikutnya. Semoga makalah ini berguna bagi penulis pada khususnya juga para pembaca yang budiman pada umumnya. 